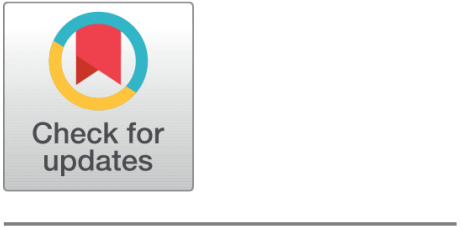

OPEN ACCESS

Received: 01.11.2020

Accepted: 01.01.2021

Published: 13.01.2021

Citation: Pancapalaga W, Suyatno , Malik A (2021) Crust leather quality with eco-printing dyeing method. Indian Journal of Science and Technology 14(1): 71-75. https://doi. org/10.17485/IJST/v14i1.1982

* Corresponding author.

Tel: +62-838-7208-7871

Pancapalaga1966@gmail.com

Funding: None

Competing Interests: None

Copyright: ( $) 2021$ Pancapalaga et al. This is an open access article distributed under the terms of the Creative Commons Attribution License, which permits unrestricted use, distribution, and reproduction in any medium, provided the original author and source are credited.

Published By Indian Society for Education and Environment (iSee)

ISSN

Print: 0974-6846

Electronic: 0974-5645

\section{Crust leather quality with eco-printing dyeing method}

\author{
W Pancapalaga ${ }^{1 *}$, Suyatno ${ }^{1}$, A Malik $^{1}$ \\ 1 Department of Animal Science, University of Muhammadiyah Malang Jl, Raya Tlogomas \\ 246, Kampus III UMM, 65151, Indonesia. Tel.: +62-838-7208-7871
}

\section{Abstract}

Background/Objectives: The eco-printing method is a dye transfer process that produces natural shapes of leaves and flowers on sheep leather. The research objective aimed at determining the quality of sheep crust leather using the eco-printing method. Methods/Statistical analysis: The research applied the experimental method using sixteen sheets of sheep crust leather. The study employed a completely randomized design. The treatments involved soaking the crust leather in a mordant of alum solution with several soaking times, namely $(\mathrm{T} 0)=0$ hours, $(\mathrm{T} 1)=12$ hours, $(\mathrm{T} 2)=24$ hours, and $(\mathrm{T} 3)=36$ hours; each of the treatments was repeated four times. The research variables included wet rubbing resistance, sweat resistance, washing resistance, tear strength, elongation, and seam strength. The data were analyzed using anova. Findings: The results showed that the soaking time did not significantly affect $(P>0.05)$ on tear strength, elongation, and seam strength. However, it had a significant effect $(p<0.05)$ on wet rubbing resistance, sweat resistance, and washing resistance. Therefore, the crust leather soaked in the mordant of Aluminum potassium sulfate for 36 hours before being dyed using the ecoprinting method did not show any decrease in its physical quality. It even showed some improvements of wet rubbing resistance with the value of 4 and 5 , sweat resistance with the value of 4 , and washing resistance with 4 to 5 . Novelty/Applications: Natural dyeing using the eco-printing method can be applied to sheep crust leather to improve the quality of wet rubbing resistance, sweat resistance, and washing resistance. It is also recommended that crust leather be soaked in Aluminum potassium Sulfate's mordant solution for 36 hours.

Keywords: Crust; ecoprinting; leather; quality; sheep

\section{Introduction}

Leather products are generally dyed with synthetic materials. Synthetic dyes have several benefits, such as giving an attractive appearance to leather products, having various color tones, and easy-to-use. However, synthetic dyeing materials are not environmentally friendly; their waste can be hazardous as some synthetic dyeing materials may be degraded into carcinogenic and toxic compounds ${ }^{(1)}$. 
Nowadays, the use of natural dyes for leather has been increasing. Several previous studies have investigated the use of some natural dyes on leather, such as Bixa orellana seed extracts ${ }^{(2)}$, Henna leaf extracts (Lawsonia inermis) ${ }^{(3)}$, and Marigold flower extracts (Tagetes erecta L.) ${ }^{(4)}$.

One of the natural dyeing methods used on leather is the eco-printing method. This method is a natural dyeing process different from any other methods commonly used in the community; it transfers dyes and produces natural forms of the plants, such as leaves and flowers, fruits, vegetables, and waste materials directly on leather. The eco-printing method is used to decorate the leather surface with various shapes and dyes from natural materials ${ }^{(5)}$.

Currently, eco-printing dyes are broadly applied to textiles, like cotton, cotton-polyester blend, and Tencel cotton blend ${ }^{(5)}$. Another study compares eco-printing on wool, silk, cotton, and flax ${ }^{(6)}$. However, eco-printing on leather has not been widely studied.

Teak leaves (Tectona grandis) are natural ingredients used for the eco-printing method because they contain $6.4 \mathrm{mg} / \mathrm{g}$ of anthocyanin pigments. Besides, they have natural dyes consisting of pheophytin, beta carotene, pelargonidin 3-glucoside, pelargonidin 3,7 -di-glucosides, and chlorophyll ${ }^{(7)}$. Teak leaves (Tectona grandis) can be used as natural dyes because they contain anthocyanins as a brown color source ${ }^{(8)}$. Anthocyanins are amphoteric compounds that can react with both acids and alkalis. Their color and stability are influenced by $\mathrm{pH}$, light, temperature, and structural components, including sugar groups and metal ions ${ }^{(9)}$. Nevertheless, not all-natural dyes can directly dye crust leather; therefore, an auxiliary substance called a mordant is required.

The use of mordants partly determines the success of natural dyeing on leather. The Mordanting process itself is a fixation process that functions to strengthen the color and change the natural dye substances according to the type of metal that binds them.

The natural dye fixation process depends on mordant concentration, soaking time, and steaming temperature. Steaming time is the main factor that influences the eco-printing method. Various types of mordants, such as copper sulfate, ferrous sulfate, potassium permanganate, and potassium sulfate, are reported to be used on leather, with the result showing that they improve leather's rubbing resistance and light resistance ${ }^{(10,11)}$. Also, it is found that certain types of mordants used on leather may greatly determine the quality of rubbing resistance, washing resistance, and sweat resistance ${ }^{(12)}$. Therefore, this study examines the quality of crust leather dyed naturally with teak leaves using the eco-printing method and aluminum Potassium Sulfate as the mordant.

\section{Materials and Methods}

Sixteen sheets of sheep crust leather were used as the primary materials. Teak leaves (Tectona grandis) were utilized as the natural dye source in the eco-printing process. Other materials included alum or aluminum potassium sulfate, sodium sulfide, ammonium sulfate, oropon, salt, basic chromium sulfate, sulfuric acid, and syntans. Meanwhile, the instruments used in this study were a crockmeter to test leather wet rubbing resistance, a universal testing machine to test leather tear strength, and a strength tester to measure leather elongation.

The leather tear strength refers to the maximum force required to tear the samples. It is in line with the sewing thread's tension with the distance between two holes of $6 \mathrm{~mm}$ and expressed in $\mathrm{N} / \mathrm{cm}$. The tear strength test was carried out based on the Indonesian National Standard (SNI) 06-1794-1990.

Leather elongation refers to the increase in the leather length when it is pulled until it breaks divided by the original size; it is expressed in percent. The elongation test was carried out according to the Indonesian National Standard (SNI) 06-1795-1990 utilizing a strength tester.

Seam strength test was conducted using a tensile strength tester and followed the Indonesian National Standard (SNI) 061117-1989.

A wet rubbing resistance test was carried out using a crockmeter. Evaluation of the test results was done by comparing dye stains of the scouring cloth to those of grayscale according to the Indonesian National Standard (SNI) 06-0996-1989.

Color resistance test against washing was conducted using the Indonesian National Standard (SNI) 08-0288-1998 method. The stages included taking samples and washing them with a laundymeter. The assessment was carried out by comparing the leather discoloration to the standard color change of grayscale.

Sweat resistance and washing resistance tests were carried out using the Indonesian National Standard (SNI)105-E04: 2010 method.

Implementation of crust leather tanning

Table 1 explains the stages of making crust leather. 
Table 1. Crust leather tanning process

\begin{tabular}{|c|c|c|c|c|}
\hline Process & $\%$ & Product & Time Duration & Remark \\
\hline Soaking & 500 & Water & 1 hour & \\
\hline \multirow[t]{3}{*}{ Liming and unhairing } & 100 & Water & & \\
\hline & 4 & Lime & & \\
\hline & 2 & Sodium sulfide & 4 hours & pH 11-12 \\
\hline \multirow[t]{3}{*}{ Deliming and bating } & 100 & water & & \\
\hline & 1.5 & Ammonium sulfate & & \\
\hline & 1 & Bating agent (oropon) & 2 hours & $\mathrm{pH} 8-8.5$ \\
\hline Washing & 200 & Water & 15 minutes & drain \\
\hline \multirow[t]{3}{*}{ Pickling } & 100 & water & & \\
\hline & 10 & Salt & & \\
\hline & 0.75 & Sulphuric acid (dilute 1:10) & 2 hours & $\mathrm{pH} 2.8-3$ \\
\hline Tanning & 8 & Basic Chromium Sulfate & 4 hours & \\
\hline \multirow[t]{2}{*}{ Basification } & 1 & Sodium formate & 45 minutes & \\
\hline & 0.5 & Sodium bicarbonate & 60 minutes & $\mathrm{pH} 4$ \\
\hline Washing & 300 & Water & 10 minutes & Drain, piling overnight \\
\hline Neutralization & 0.75 & Sodium bicarbonate & $3 \times 15$ & pH 5-5.5 \\
\hline \multirow[t]{3}{*}{ Retanning } & 100 & Water & & \\
\hline & 8 & Syntan & 90 minutes & \\
\hline & 9 & Synthetic fatliqour & 90 minutes & \\
\hline Fixing & 1 & Formic acid & $3 \times 10+30$ & $\mathrm{pH} 3.5$ \\
\hline Washing & 300 & Water & 10 minutes & \\
\hline
\end{tabular}

\section{Implementation of the eco-printing dyeing method}

Firstly, a mordant solution was formulated by dissolving 70 grams of aluminum potassium sulfate in 1 liter of water. Then, the leather was soaked in the mordant solution with several different treatments of soaking time, namely (T0 = 0 day); (T1 = 12 hrs); (T2 = $24 \mathrm{hrs})$; (T3 = $36 \mathrm{hrs})$. After being dried, the leather was placed on a plastic sheet. Next, teak leaves (Tectona grandis) were stuck to the leather surface and arranged according to the desired model. Then, the leather was rolled with plastic and tied up using a rope. Subsequently, the tied leather was steamed for an hour. After being cooled down, the leather ties were opened, and the teak leaves were removed. Eventually, the leather was dried in a room before being proceeded to the laboratory testing.

\section{Data analysis}

The grayscale value determines the level differences or dye concentration from the lowest to the highest (value 1 to 5 ). It used the International Standard Organization (ISO) standard, namely the grayscale standard for dye changes. The data of wet rubbing resistance, sweat resistance, and washing resistance were tabulated and analyzed using the Kruskall Wallis test. It was then followed with the Mann Whitney test to find out the differences among the treatments. Meanwhile, the data of tear strength, elongation, and seam strength were analyzed using anova to determine the difference among each treatment. When the treatment had a significant effect, it subsequently proceeded with the Duncan test.

\section{Results and Discussion}

The findings are presented in Tables 2 and 3.

Table 2. Crust leather quality after soaked with the Aluminum potassium sulfate mordant

\begin{tabular}{lllll}
\hline \multirow{2}{*}{ Variable } & \multicolumn{3}{c}{ Soaking time (hour) } \\
\cline { 2 - 5 } & 0 hour & 12 hours & 24 hours & 36 hours \\
\hline Tear strength $(\mathrm{N} / \mathrm{cm})$ & $131.030^{\mathrm{a}}$ & $142.745^{\mathrm{a}}$ & $137.465^{\mathrm{a}}$ & $147.587^{\mathrm{a}}$ \\
Elongation (\%) & $75.360^{\mathrm{a}}$ & $74.580^{\mathrm{a}}$ & $69.350^{\mathrm{a}}$ & $63.035^{\mathrm{a}}$ \\
Seam strength $(\mathrm{N} / \mathrm{cm})$ & $571.337^{\mathrm{a}}$ & $584.052^{\mathrm{a}}$ & $605.730^{\mathrm{a}}$ & $721.825^{\mathrm{a}}$ \\
\hline
\end{tabular}

Note: The same notation (a) shows no significant difference $(\mathrm{P}>0.05)$ 
Table 3. Kruskal Wallis results of different soaking time treatments with Aluminum potassium sulfate mordant

\begin{tabular}{lllll}
\hline Treatment & Chi-Square value & Df & Asynp.sig & Conclusion \\
\hline Wet rubbing resistance & 10,402 & 3 & 0,011 & Showing a significant difference $(\mathrm{P}<0,05)$ \\
Washing resistance & 9,377 & 3 & 0,022 & Showing a significant difference $(\mathrm{P}<0,05)$ \\
Sweat resistance & 9,420 & 3 & 0,014 & Showing a significant difference $(\mathrm{P}<0,05)$ \\
\hline
\end{tabular}

Table 2 shows that the 36-hour of soaking time does not have any significant effect $(\mathrm{P}>0.05)$ on tear strength, elongation, and seam strength of the crust leather. It indicates that soaking the crust leather in the mordant of Aluminum potassium sulfate does not change either the physical quality or structure of the crust leather as its structure, especially on the corium part, has already been bound by the tanner.

Seam strength can be affected by leather thickness, content and density of collagen protein, adjacent collagen fibers' angles, and corium thickness. Seam strength is directly proportional to tensile strength and tear strength. If both tensile and tear strength are high, the seam strength is also high. Thin leather has loose collagen fibers; thus, it has lower tear strength than thicker leather ${ }^{(13)}$. Woven shape, the density of collagen fiber bundles, collagen fiber integrity, and angles of woven corners determine the amount of tensile strength and leather elasticity. Leather with high tensile strength generally has low elasticity; on the other hand, leather with low tensile strength is prone to have high elasticity ${ }^{(14)}$.

Besides, the adherence of natural dyeing substance cannot permanently remain on leather; thus, a specific chemical binding called a mordant is essential ${ }^{(15)}$. Mordant, also known as mordere or bite, is metal salt functioning as a means for dye absorption, dye absorption acceleration, a chemical bridge between dye molecules and leather tissue, and chemical agent to generate permanent dyes ${ }^{(16)}$.

Aluminum potassium sulfate accelerates the absorption of natural dyes and functions as a tanning material. However, the crust leather used in this study has already been tanned with basic chromium sulfate and syntans. Hence, aluminum potassium sulfate does not have much role as the tanning material. It can be seen from the findings showing that 36-hour of soaking time with alum does not affect tear strength, elongation, and seam strength.

The results of leather's physical quality show that both soaked and unsoaked leather have the same quality. The tanning process much influences the physical quality of leather. The combination of vegetable and chromium tanned leather produces higher seam strength than permanent single tanning leather ${ }^{(17)}$. Seam efficiency increases along with seam strength; however, the efficiency declines if breaking strength and permanent tensile strength are high ${ }^{(18)}$.

Table 3 illustrates that the duration of soaking leather in the alum mordant up to 36 hours affects $(\mathrm{P}<0.05)$ both wet and dry scrubbing resistance, washing resistance, and sweat resistance of crust leather with eco-print dyes. During the soaking period, aluminum potassium sulfate has the opportunity to bind leather tissues more perfectly; thus, it can increase the leather wet rubbing resistance, washing resistance, and sweat resistance.

The same thing occurs with silk cloth. The study has found that silk cloth soaked with mordant can increase its color strength, brightness, and resistance more intensively than that without mordant ${ }^{(19)}$.

Several essential mordants that can be used are potassium dichromate, iron sulfate, copper sulfate, zinc sulfate, tannins, and tannic acid. Mordants are chemical substances that form chemical bonds with natural dyes. The chemical bond between mordant and natural dyes is initially formed by soaking leather in a mordant solution before dyeing the leather. This process can help absorb and fix natural dyes, prevent leather from dye fading, and improve color-resistance ${ }^{(20)}$.

Meanwhile, Suede dyes from a mixture of sodium chloride and aluminum sulfate can produce a brighter dye for printed leather ${ }^{(21)}$.

\section{Conclusion}

The quality of wet rubbing resistance, sweat resistance, and washing resistance of crust leather dyed naturally with teak leaves using the eco-printing method can increase when soaked with the Aluminum potassium sulfate mordant for 36 hours. Besides, it does not reduce crust leather's physical quality, such as tear strength, elongation, and seam strength.

\section{Acknowledgement}

The authors would like to thank the Rector of the University of Muhammadiyah Malang and the Directorate of Research and Community Service, University of Muhammadiyah Malang for facilitating this study. 


\section{References}

1) Berhanu T, Ratnapandian S. Extraction and Optimization of Natural Dye from Hambo Hambo(Cassia singueana)Plant Used for Coloration of Tanned Leather Materials. Advances in Materials Science and Engineering. 2017;2017(6):1-5. Available from: https://dx.doi.org/10.1155/2017/7516409.

2) Selvi AT, Aravindhan R, Madhan B, Rao JR. Studies on the application of natural dye extract from Bixa orellana seeds for dyeing and finishing of leather. Industrial Crops and Products. 2013;43:84-86. Available from: https://dx.doi.org/10.1016/j.indcrop.2012.07.015.

3) Musa AE, Madhan B, Madhulatha W, Rao J, Gasmelseed GA, Sadulla S. Coloring of Leather using Henna - Natural Alternative Material for Dyeing. Journal-American Leather Chemists Association. 2008;104(5):183-190. Available from: https://journals.uc.edu/index.php/JALCA/article/view/2483.

4) Pervaiz S, Mughal TA, Khan FZ, Hayat FS, Aslam A, Shah SF. Environmental friendly leather dyeing using Tagetes erecta L. (Marigold) waste lowers. International Journal of Biosciences. 2017;10:382-390. Available from: http://dx.doi.org/10.12692/ijb/10.1.382-390.

5) Izmal OE. Patterns from Nature: Contact Printing. Journal of the TEXTILE Association. 2016;77(2):81-91. Available from: https://issuu.com/ textileasociationindia/docs/e-journal_-_jul-aug_16.

6) Rekabya M, Salemb AA, Nassara SH. Eco-friendly printing of natural fabrics using natural dyes from alkanet and rhubarb. Journal of the Textile Institute. 2009;100(6):486-495. Available from: https://doi.org/10.1080/00405000801962177.

7) Murukan G, K M. Composition of Purified Anthocyanin Isolated From Teak and It's in Vitro Antioxidant Activity. International Journal of Pharmacy and Pharmaceutical Sciences. 2017;9(9):258-266. Available from: https://dx.doi.org/10.22159/ijpps.2017v9i9.19517.

8) Qadariyah L, Mahfud M, Sulistiawati, Swastika P. Natural Dye Extraction from Teak Leves (Tectona Grandis) Using Ultrasound Assisted Extraction Method for Dyeing on Cotton Fabric. MATEC Web of Conferences. In: and others, editor. The 24th Regional Symposium on Chemical Engineering;vol. 156. 2017. Available from: https://doi.org/10.1051/matecconf/201815605004.

9) Fennema OR, and LKP. Food Chemistry. Damodaran S, et al., editors;New York. Marcel Dekker Inc. 2008.

10) Mughal AT, Shamsheer B, Zaheer S. Ecofriendly Leather Dyes Extracted from Plants Bark. Germany. LAP Lambert Academic Publishing. Publication Saarbrucken. 2012

11) Onem E, Gulumser G, Ocak B. Evaluation of Natural Dyeing of Leather with Rubia tinctorum Extract. Ekoloji. 2011;20:81-87. Available from: https://doi.org/10.5053/ekoloji.2011.8011.

12) Pervaiz S, Mughal TA, Khan FZ. Leather Dyeing with Plants Dyes: A Review. Journal of Biodiversity and Environmental Sciences. 2016;9(1):455-464.

13) Kanagy JR, Flaherty F, Roddy WT, Lollar RM. Physical and Performance Properties of Leather. In: O'Flaherty F, Roddy WT, Lollar RM, et al., editors. The Chemistry and Technology of Leather;vol. 4. Florida. Krieger Publishing Company. 1977.

14) Lawal A, Odums C. Tanning of Different Animal Skins/Hides and Study of Their Properties for Textile Application. British Journal of Applied Science \& Technology. 2015;5(6):588-594. Available from: https://dx.doi.org/10.9734/bjast/2015/12938.

15) Aravindhan R, Madhan B, Thanikaivelan P, Kanth VS, Rao JR, Gnanasekaran CS, et al. Upgradation of leathers: Masking defects using pigments in pre-finishing processes. Journal of scientific and industrial research. 2008;67(3):233-238. Available from: http://hdl.handle.net/123456789/772.

16) Griyanitasar G. Pengaruh Penambahan Jumlah Pigmen Pada Lapisan Dasar (Base Coat) Pada Proses Finishing Terhadap Sifat Fisik Kulit Sapi. Buletin Peternakan. 2017;41(3):318-318. Available from: https://doi.org/10.21059/buletinpeternak.v41i3.16649.

17) Nilay O, Mete MM, Zeynep YE, Oktay P. Sewability Properties Of Garment Leathers Tanned With Various Tanning Materials. In: and others, editor. International Scientific Conference "Innovative solutions for sustainable development of textiles and leather industry;vol. 17. 2017;p. 197-202.

18) Phebe K, Thanikaivelan P, Krishnaraj K, Chandrasekaran B. Factors Influencing the Seam Efficiency of Goat Nappa Leathers. Journal- American Leather Chemists Association. 2012;107(3):78-84. Available from: https://journals.uc.edu/index.php/JALCA/article/view/3387/2638.

19) Rungruangkitkrai N, Mongkholrattanasit R. Eco-Friendly of Textiles Dyeing and Printing with Natural Dyes. In: RMUTP International Conference: Textiles \& Fashion. 2004.

20) Prabhu KH, Bhute AS. Plant based natural dyes and mordnats: A Review. J Nat Prod Plant Resour. 2012;296:649-664. Available from: http: //scholarsresearchlibrary.com/archive.html.

21) Boahin JOB, Adu-Agyem J, Peligah YS. Exploring the use of suede dye on leather. Journal of Science and Technology (Ghana). 2011;31(2):68-73. Available from: https://dx.doi.org/10.4314/just.v31i2.69395. 